\title{
Academic Failure in Higher Education: Socio-Cultural Analysis from the Perspectives of Students and Teachers in Mexico ${ }^{+}$
}

\author{
Leticia Nayeli Ramírez-Ramírez ${ }^{1}$, Santiago Gallur-Santorun ${ }^{2}$ and Jorge Garcia-Villanueva 3,* \\ 1 Escuela de Humanidades y Educación, Tecnológico de Monterrey, 64849 Monterrey, Mexico; \\ leticia.rmrz@itesm.mx \\ 2 Departamento de Humanidades, Universidad Autónoma de Ciudad Juárez, Ciudad Juárez, \\ 32310 Chihuahua, Mexico; santiago.gallur@uacj.mx \\ 3 Área Académica 2. Diversidad e Interculturalidad, Universidad Pedagógica Nacional, \\ 14200 Ciudad de México, Mexico \\ * Correspondence: jvillanueva@upn.mx \\ + Presented at the 2nd Innovative and Creative Education and Teaching International Conference \\ (ICETIC2018), Badajoz, Spain, 20-22 June 2018.
}

Published: 26 October 2018

\begin{abstract}
This research is part of an inter-institutional project interested in analyzing the perceptions of students and teachers about the factors that affect academic failure. In this paper, academic failure is seen, form the sociocultural approach as a complex phenomenon in which different educational actors take place and are related to personal, social, economic and institutional factors. Sociocultural studies have paid attention to the understanding of educational problems by pointing out as an important mediator the social and cultural context from which students come and the divergences between home/social and academic cultures that are played within the microsocial contexts of the schools and classrooms. Thus, in this work, academic failure is seen as the interplay between personal, social, economic and institutional factors that enable or not the student to integrate into the academic community, build a sense of belonging/commitment to it and perform with success in their university studies.
\end{abstract}

Keywords: academic failure; higher education; students and teachers

\section{Introduction}

Higher Education in Mexico has historically had different challenges and vicissitudes to face. Currently, one of the most important challenges in the agendas of Higher Education Institutions (IES) revolves around ensuring access and permanence of students to tertiary studies (higher education). Thus, the statistics worldwide reported by UNESCO (2018) show that the gross enrollment rate at the tertiary level reported between 2010 and 2014 in Mexico ranges from $26.17 \%$ to $29.21 \%$, respectively, which places it at below the enrollment that reports for the same range of dates Chile $(69.67 \%$ to 86.63\%), Brazil (N/A-49.28\%), Colombia (39.40\% to 53.28\%) and Argentina (73.94\% to $82.92 \%)$. In the same tenor, the report of the Organization for Economic Cooperation and Development [1] points out that despite the improvements achieved in education, only $17 \%$ of young people between 25 and 64 years of age they had completed Higher Education in 2016, placing Mexico in the lowest proportion among the OECD countries with students enrolled in the university. 


\section{Theoretical Framework}

Several researchers have taken up the proposal of de Tinto of the 70s [2] to refer to the integration of university students, introducing another concept related to academic reprobation such as participation in social life within and outside the universities. From this proposal, the integration of the student within an institution can occur along two dimensions; the academic and social. Academic integration occurs when students feel attached to the intellectual life of the university, while social integration occurs when students create relationships and connections outside the classroom that give them a sense of belonging to the institution, both processes are interconnected and they favor the student's stay in the university.

In this line of thought, socio-cultural studies have contributed to the understanding of educational problems by pointing out as an important mediator the social and cultural context from which students come and the divergences between the home/social and academic cultures that are played within of the microsocial contexts of schools and classrooms [3]. Therefore, the research questions that guided this case study revolve around: (1) what are the divergences/similarities between the perceptions that educational actors display about the phenomenon of academic failure. (2) What Units of meaning deploy students and teachers around the factors of academic failure? The general objective of the research is to analyze the perceptions of students and teachers about the factors that affect academic failure in a public university located in the border area of Ciudad Juarez. The specific objectives are two: (1) to analyze the differences between the factors of academic failure perceived by teachers and students; (2) understand, through the analysis of qualitative content, the units of meaning displayed by teachers and students around academic reprobation.

\section{Method}

The present research is ascribed to the approach of interpretative research, with intrinsic case study design, which consists of an approach to a particular situation in a profound way and with information from various sources at first hand for the understanding of a phenomenon that is presented in an unusual or unique way. The case study methods are aided by direct observations, numerical data, documents, and extensive data collection in the natural environments in which the participants are situated [4,5]. The selection of the sample was carried out by means of a nonprobabilistic sampling by quotas, in which groups of 25 students were chosen with the following characteristics: active academically for the 2016-1 school year, in morning and evening shifts, which they will study some of the degree programs that are offered in the institutes of arts, engineering, social sciences and biomedical sciences. The total sample consisted of 620 students.

\section{Data Collection}

The data collection instruments that were used were participant observations, informal interviews through field diary, compilation of public and institutional documents and the construction of a questionnaire with 19 items for each of the actors, students and teachers, which was formed by a section of closed questions with a 4-level Likert type response option (Always, Often, Sometimes, Never) and a section of open questions in which students and teachers could express their perception in writing about academic reprobation. The ethical considerations that were taken throughout the process of data collection and analysis were the anonymity of the educational institution and of all the participants of the research through the informed consent embodied in the questionnaires and in the verbal interactions that were held with the educational actors.

\section{Results}

\subsection{Factors of Academic Failure Perceived by Students}

It is worth mentioning, from the perceptions of the students of Campus 1, the factors that were never present for the academic failing and that are not significant in the occurrence of the same are the following: Economic and/or labor situation of the student (56\% never), personal and/or family 
problems ( $43 \%$ never), lack of timely tutoring/counseling ( $49 \%$ never), access to materials, books, impressions, internet (52\% never). See Figure 1.

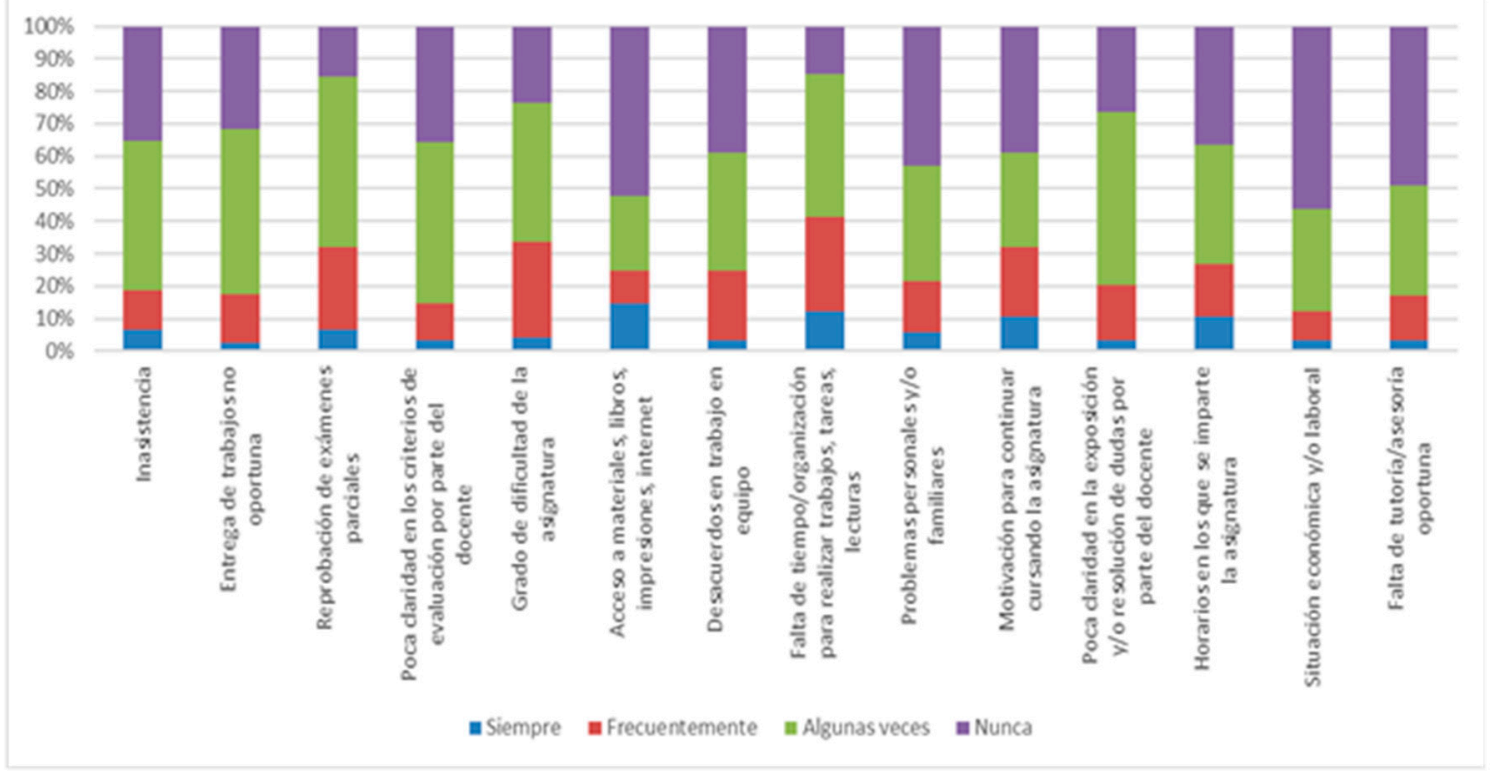

Figure 1. Percentage of factors of academic failure perceived by Campus 1 students.

\subsection{Factors of Academic Failure Perceived by Teachers}

In relation to the perceptions of the teachers of Campus 1, it was found that the dimensions with a high-frequency index were the following: (1) School factors: Absences (50\% sometimes), unsuitable work delivery (70\% sometimes), failure of partial exams ( $68 \%$ sometimes), degree of difficulty of the subject (38\% sometimes); (2) Institutional-social factors: Access to materials, books, internet (33\% always); (3) Interpersonal factors of the student: Lack of time/organization to perform work, assignments, readings ( $36 \%$ sometimes), personal/family problems (63\% sometimes), motivation to continue in the subject (50\% sometimes). In contrast, the factors that teachers identify as having zero incidences in academic failure were: Poor clarity in the evaluation criteria (54\% never), poor clarity in the presentation and/or resolution of doubts by the teacher (54\%) never), schedules in which the subject is taught (50\% never), disagreement in teamwork (50\% never), economic/work situation ( $47 \%$ never), lack of timely tutoring/advice ( $47 \%$ never).

\subsection{Qualitative Content Analysis}

Based on the answers to the open questions posed in the last section of the questionnaire and which dealt with the perception of the student or teacher about the factors of academic failure, a qualitative analysis of conventional content was carried out (Hsieh \& Shannon 2005) in the one that was coded through an inductive process the answers of teachers and students, using the MAXQDA (C) digital tool. In total 24 codes were generated expressed in a matrix of relationships (see Table 1) in which the frequencies of codes between each of the groups analyzed are shown (Teachers campus 1/Students campus $1 /$ Teachers campus 2/Students campus 2). 
Table 1. Matrix of relation of the frequency of codes generated from content analysis.

\begin{tabular}{ccccc}
\hline Códigos & $\begin{array}{c}\text { Docentes } \\
\text { Campus 1 }\end{array}$ & $\begin{array}{c}\text { Estudiantes } \\
\text { Campus 1 }\end{array}$ & $\begin{array}{c}\text { Docentes } \\
\text { Campus 2 }\end{array}$ & $\begin{array}{c}\text { Estudiantes } \\
\text { Campus 2 }\end{array}$ \\
\hline Estudiantes con capacidades diferentes & 0 & 2 & 0 & 0 \\
Formación académica del docente & 0 & 4 & 0 & 0 \\
Deserción escolar & 2 & 0 & 1 & 0 \\
Problemas personales estudiantes & $\mathbf{2}$ & $\mathbf{1}$ & $\mathbf{3}$ & 0 \\
Incumplimiento del estudiante & $\mathbf{6}$ & 0 & $\mathbf{1 0}$ & 0 \\
Antecedentes académicos del estudiante & 1 & 0 & 2 & 0 \\
Motivación del estudiante & $\mathbf{9}$ & 0 & $\mathbf{7}$ & 1 \\
Estrategias de aprendizaje del estudiante & 5 & 3 & 4 & 0 \\
Factores institucionales & 1 & 4 & 0 & 6 \\
Cumplimiento institucional del docente & 0 & $\mathbf{7}$ & 0 & $\mathbf{1 1}$ \\
Docente y tutorías & 0 & 3 & 0 & 3 \\
Relación personal docente-estudiante & 0 & $\mathbf{2 6}$ & 0 & $\mathbf{1 3}$ \\
Innovación en clases & 0 & 1 & 0 & 1 \\
Instrumentos de evaluación & 0 & $\mathbf{1 0}$ & 0 & $\mathbf{9}$ \\
Estudiantes que estudian y trabajan & $\mathbf{4}$ & $\mathbf{7}$ & 0 & $\mathbf{1 0}$ \\
Apoyo emocional al estudiante & 0 & 11 & 0 & 22 \\
Adaptación de las estrategias de enseñanza & 0 & 8 & 0 & 22 \\
Ayuda y apoyo del docente & 0 & $\mathbf{4 9}$ & 0 & 24 \\
Factores relativos al estudiante & 1 & $\mathbf{1 9}$ & 0 & $\mathbf{1 9}$ \\
Criterios de evaluación del docente & 0 & $\mathbf{3 6}$ & 0 & $\mathbf{4 6}$ \\
Clases virtuales & 1 & 6 & 0 & 1 \\
Técnicas didácticas docente & 0 & $\mathbf{1 3 3}$ & 0 & $\mathbf{1 1 1}$ \\
\hline
\end{tabular}

\section{Discussion}

According to the findings documented in the research, the perceptions of students and teachers about academic failure show variations in the relevance or frequency with which they value the analyzed dimensions, namely: School factors, Institutional-social factors, Interpersonal factors of the student and Factors of the teacher. On the one hand, the students of both campuses value as significant the school, institutional-social and teacher factors. And on the other hand, the teachers consider relevant the interpersonal factors of the student, school, and institutional-social. This data points to a divergence in the perception of academic failure by both actors of the educational process and coincides with that reported by [6] on the perceptions of students focused on the little concern of teachers towards the level of student performance in class, the motivations and teaching strategies deployed by teachers in the university classroom.

From a sociocultural perspective, we agree with the main thesis of the theory of academic and social integration proposed by [7]; students fail at school because they are not sufficiently integrated into some aspects of the university. Some factors reported in this research that influenced the integration of the students with the academic community are the living conditions of the students (social marginalization and occupation), the adaptation to the university, institutional conditions, divergences between students and teachers, and the commitment that the student assumes within the university. Likewise, a relevant fact that emerges from the research is the interaction process that takes place in the classroom and that appears in the perceptions of teachers and students in a contradictory and inverted way.

Author Contributions: The main author L.N.R.-R. carried out and planned the research and the manuscript. The second author S.G.-S. contributed to the analysis of the literature and half of the writing. The last author J.G.-V. contributed in the analysis of data and the writing of the discussion. 
Conflicts of Interest: The authors declare no conflict of interest.

\section{References}

1. OCDE. Panorama de La Educación 2017: Indicadores de La OCDE. Mexico; 2017. Available online: http://uis.unesco.org/indicator/edu-part-er-ger (accessed on 5 January 2018).

2. Mechur, M.; Hughes, K.L. An Exploration of Tinto's Integration Framework for Community College Students. J. Coll. Stud. Retent. 2011, 12, 69-86, doi:10.2190/CS.12.1.e.

3. Dressman, M.; Wilder, P.; Connor, J.J. Theories of Failure and the Failure of Theories: A Cognitive/Sociocultural/Macroestructural Study of Eight Struggling Students. Res. Teach. Engl. 2005, 40, 8-61.

4. Creswell, J.; Poth, C. Qualitative Inquiry and Research Design. Choosing among Five Approaches, 4th ed.; Creswell, J., Poth, C., Eds.; SAGE Publications, Inc.: Thousand Oaks, USA, 2018.

5. Yin, R.K. Case Study Methods. In Handbook of Complementary Methods in Education Research, 3rd ed.; Green, J.L., Camilli, G., Elmore, P.B., Eds.; American Educational Research Association: Washington, DC, USA, 2006; pp. 111-122.

6. Hernández, C. Diagnóstico del rendimiento académico de estudiantes de una escuela de educación superior en México. Rev. Complut. Educ. 2016, 27, 1369-1388, doi:10.5209/rev_RCED.2016.v27.n3.48551.

7. Tinto, V. Definir la deserción: Una cuestión de perspectiva. Rev. Educ. Super. 1989, XVIII, 1-9.

(C) 2018 by the authors. Licensee MDPI, Basel, Switzerland. This article is an open access article distributed under the terms and conditions of the Creative Commons Attribution (CC BY) license (http://creativecommons.org/licenses/by/4.0/). 